\title{
Sorption reseaches on the removal of the bond ammonia from the wastewater
}

ElEonora BUTENKO - Azov Sea State Technical University, Mariupol, Ukraine - butenkoeo@rambler.ru Érkezett: 2018. 02. 14. " Received: 14. 02. 2018. " https://doi.org/10.14382/epitoanyag-jsbcm.2019.15

Eleonora BUTENKO PhD, assistant professor. She's learned of Donetsk National University (2002-2007). She has been working of Azov Sea State Technical University from 2007. Now she is Deputy Head of Department of Chemical Engineering and Technology of Azov Sea State Technical University. She is the author more than 70 scientific articles and two monographs.

\begin{abstract}
Examined the formation of free and bound ammonia in various coking processes, the existing processes of capture and the impact of ammonia on the environment. Layered double hydroxide sorbents of different composition were obtained and investigated. The activity and selectivity of layered double hydroxides in the process of sorption of ammonia and its derivatives was investigated. It is shown that the main factor affecting the rate of the process is the strength of the basic sites. The efficiency of the use of sorbents for the removal of ammonia from the environment has been evaluated.

Keywords: ammonia water, coke oven production, anionic clays, sorption, kinetics, bound ammonia, free ammonia

Kulcsszavak: ammónia-víz, kokszolókemence, anionos agyagok, szorpció, kinetika, kötött

ammónia, szabad ammónia
\end{abstract}

\section{Introduction}

Coke oven production deals with manufacturing of coal coke, coke oven gas, benzene, ethylene, different oils, resins etc. These products can be used as fuel or as raw materials for manufacturing of polymers, synthetic detergents, pesticides, nitrogen containing fertilizers and the like. The main task of coke oven production is coal treatment by means of the coking method. During such process operations like coal washing, coke quenching, gas purification from hydrogen sulphide and resin rectification water is contaminated mainly with volatile phenols, ammonia and resins [1-4]. It is also characterized by excessive concentrations of thiocyanates, sulphides, chlorides, presence of thiosulphides and values of $\mathrm{PH}$, ranging from 7.1 to 8 .

\section{Analysis of the literature data and setting the objective of investigations}

The bulk of ammonia at coal coking is formed by means of direct extraction of $\mathrm{NH}_{3}$ at pyrolysis of nitrogen containing coal compounds. The amount of nitrogen, bound into ammonia reaches $11-15 \%$ from its overall content. Ammonia recovery at coking of coals, extracted in the Donetsk basin is 0.25-0.30 $\%$, while for Kuznetsk basin coals it could be up to $0.45 \%$ per 1 ton of dry coal [5].

Ammonia is a gaseous substance, its density is $0.77 \mathrm{~kg} /$ $\mathrm{m}^{3}$. It forms, when mixed with air an explosive mixture with explosiveness limits: $14 \%$ the lower, 33\% the higher (in volume); the temperature of ignition of ammonia is 780 ${ }^{\circ} \mathrm{C}[6]$. Ammonia is a very toxic substance, it has a strong smell, tangible at its concentration in air $40 \mathrm{mg} / \mathrm{m}^{3}$. Maximal permissible concentration of ammonia in the working area of industrial premises is $20 \mathrm{mg} / \mathrm{m}^{3}$.

At low temperatures ammonia is well dissolved in water. Table 1 shows solubility of ammonia in $100 \mathrm{ml}$ of water [7].

\begin{tabular}{|c|c|c|c|c|c|c|}
\hline Temperature $\left[{ }^{\circ} \mathrm{C}\right]$ & 20 & 30 & 40 & 70 & 80 & 90 \\
\hline Solubility [g/100ml] & 53.1 & 44.0 & 30.4 & 10.4 & 6.3 & 2.6 \\
\hline
\end{tabular}

Ammonia is a valuable component of coke coals and it is economically beneficial to recover it from gas. It is a source for obtaining nitrogen fertilizer (ammonia sulphate) and it is the main reagent for extraction of pyridine bases in sulphate-pyridine department of recovery shop. Coke oven gas purification from ammonia is required due to the following reasons: at presence of oxygen, water vapours, hydrogen sulphide, and hydrogen cyanide in coke oven gas, ammonia exerts strong corroding action on the equipment and gas pipe-lines; it hampers recovery of benzol hydrocarbons from coke oven gas, as it causes rapid damage of stripping oil and violates the technological mode; when coke oven gas is used for domestic applications it forms poisonous nitrogen oxides in fire chambers. Ammonia removal from gas is an obligatory condition for normal functioning of coke oven production and it is strictly obligatory for application of coke oven gas for domestic use [8].

Ammonia removal from coke oven gas can be performed in two ways: 1) by absorption in cold water in apparatuses, that were named scrubbers, the method is based on good solubility of ammonia in water; 2) by absorption in sulphur acid in apparatuses of bubbling saturators (or absorbers), the method is based on reaction of ammonia neutralization by sulphur acid. The second method has found a wide application in industry [9]

In ammonia-tar liquor, formed at cooling of coke oven gas in cooling towers, gas collectors, or primary coolers the greater part of ammonia is in the form of various salts. Their presence in ammonia-tar liquor is explained by the fact that hydrogen sulphide, hydrogen chloride, hydrogen cyanide and other acid gases are consumed simultaneously with ammonia, the latter reacts with them, forming the corresponding salts. 
Some of these salts-ammonium carbonate $\left(\mathrm{NH}_{4}\right)_{2} \mathrm{CO}_{3}$, ammonium sulphite $\left(\mathrm{NH}_{4}\right)_{2} \mathrm{~S}$ and ammonium cyanide $\left(\mathrm{NH}_{4} \mathrm{CN}\right)$ are so unstable, that they decompose when their water solutions are heated to the temperature, close to boiling temperature, emitting ammonia and the corresponding gases: $\mathrm{H}_{2} \mathrm{~S}, \mathrm{CO}_{2}$ and $\mathrm{HCN}$. Ammonia, bound in the form of such salts is called volatile.

Ammonium chloride $\left(\mathrm{NH}_{4} \mathrm{Cl}\right)$, ammonium thiocyanate $\left(\mathrm{NH}_{4} \mathrm{SCN}\right)$, ammonium sulfate $\left(\mathrm{NH}_{4}\right)_{2} \mathrm{SO}_{4}$ belong to the group of stable compounds and they do not decompose at heating. Chemical methods of treatment are to be applied for recovery of ammonia from them. Ammonia, containing in ammoniatar liquor in the form of these salt is called bound. It can be recovered by applying alkali, like slack lime (lime milk) stronger than ammonia on them.

Ammonia-tar liquor also contains some amount of phenols, pyridine bases, light oils, and naphthalene.

Ammonia, contained in ammonia-tar liquor in the volatile form is generally called total ammonia. Chemical composition of ammonia-tar liquor is characterized by presence of total ammonia, separate volatile ammonia, acids, bases and neutral admixtures.

Ammonia and ammonium salts content in ammonia-tar liquor is essentially determined by the cooling temperature of gas. The lower this temperature is the higher is the content of total ammonia in water. Moreover, the content of total ammonia in water depends on the specified gas cooling scheme: it is smaller when gas is cooled in tubular coolers and higher, when gas is cooled in direct action coolers. Ammonia-tar liquor of gas collectors salts, containing bound ammonia prevail.

Ammonia is the main and most valuable component of ammonia-tar liquor. It contains up to $0.1 \%$ ammonia from their resources per $1 \mathrm{mt}$ of dry charge. The amount of excessive ammonia-tar liquor to undergo recycling is usually 10-12\% from the coking charge. Utilization of these vast ammonia resources at large scale of coke oven production is a task of a paramount importance, as ammonia recovered there can be used for production of ammonia sulphate and recovery of pyridine compounds. Table 2 shows an approximate composition of ammonia-tar liquor, supplied for treatment (at mixing of drainage from gas collectors and primary coolers), in $\mathrm{g} / \mathrm{l}$.

Modern process flow sheets of recycling of ammonia-tar liquor are closely connected with functioning of sulfate and pyridine departments and phenol-removing unit.

The process of distillation is used for recycling of ammoniatar liquor, i.e. recovery of the solved ammonia from ammoniatar liquor by means of live steam in distillation columns, equipped with bubble cup plates at $100-102{ }^{\circ} \mathrm{C}$.

\begin{tabular}{|c|c|}
\hline Total & 7.0 \\
\hline Volatile & 3.0 \\
\hline $\mathrm{H}_{2} \mathrm{~S}$ & 1.3 \\
\hline $\mathrm{CO}_{2}$ & 1.3 \\
\hline Phenols & $1.5-2.0$ \\
\hline Pyridine compounds & $0.4-0.5$ \\
\hline
\end{tabular}

Recycling of ammonia-tar liquor includes the following process operations: distillation of volatile ammonia from ammonia-tar liquor in evaporation column, phenol removal from water by means of live-steam method; decomposition of salts of bound ammonia inside the reactor by a solution of slack lime; distillation of bound ammonia in the column of bubble cup type [10].

The process of recovery of volatile ammonia from ammoniatar liquor is based on a drastic reduction of solubility on water of ammonia, carbon dioxide, hydrogen sulphate, hydrogen cyanide, at water heating up to $98-100^{\circ} \mathrm{C}$. At that decomposition of carbonates, sulphides, and cyanides takes place with recovery of ammonia and other gases, according to the following reactions:

$$
\begin{gathered}
\left(\mathrm{NH}_{4}\right)_{2} \mathrm{CO}_{3}->2 \mathrm{NH}_{3}+\mathrm{CO}_{2}+\mathrm{H}_{2} \mathrm{O}, \\
\left(\mathrm{NH}_{4}\right)_{2} \mathrm{~S}->2 \mathrm{NH}_{3}+\mathrm{H}_{2} \mathrm{~S}, \\
\mathrm{NH}_{4} \mathrm{CN}->\mathrm{NH}_{3}+\mathrm{HCN} .
\end{gathered}
$$

Ammonia-tar liquor of plants, where coals from the Donetsk basin are used has an increased content of bound ammonia salts ( 4 to $7 \mathrm{~g} / \mathrm{l})$.

However, the described methods do not permit to get fully rid of ammonia ions. Wastewaters contain sufficiently big amounts of ammonia ions. Water, drained into the Azov Sea, which is not completely recycled contaminates it and also underground waters.

\section{The objective and tasks of investigations}

The problem of removal of ammonia nitrogen from water is a vital one, as pollution of underground waters inevitably leads to pollution of fresh waters. Constant consumption of water, containing increased content of ammonia may cause chronic acidosis and changes in tissues. Moreover, there is a danger of uncontrolled nitrification resulting in formation of nitrites as an intermediate product, negative influence of which upon human organism is quite substantial. That is why purification of wastewaters from coke oven production is quite topical.

Various methods of additional purification, like, for instance, coagulation, bio-filtration, ionite purification, reverse osmosis, sorption methods with application of different sorbents are most commonly used. Economic and ecological components of these methods of additional purification differ very much.

Most promising and economically beneficial are sorption methods of additional purification with application of anionic clays of different compositions. Synthetic anionic clays possess high selectivity to ammonia ions, they are not costly, as they are waste products of chemical industry and there cannot be any problems with their utilization as at their thermal treatment the reverse process of desorption is not possible.

\section{Experimental results}

\subsection{Recovery of double hydroxide sorbents}

There are two principal methods of recovering main sorbents of hydroxide type: mechanical and chemical method and the method of precipitation from a liquid solution. Both these methods have advantages and drawbacks of their own.

By applying the method of displacement of oxides and salts with addition of water and also hydroxides and salts hydroxides, on the basis of zinc-chromium, calcium-aluminum, 
copper-aluminum were received. The components in the corresponding, calculated quantities were placed into a glass and mixed with periodic addition of water for several hours, by means of a magnetic mixer. The biggest practical difficulty of this method is in the necessity of constant taking of samples to observe the progress of reaction, as it is impossible to determine the appearance of a new phase visually. That is why the bulk of catalysts was received by the method of basic precipitation.

By applying the method of precipitation various sorbents of hydroxide type were obtained and investigated $\left[\mathrm{Mg}_{2} \mathrm{Al}(\mathrm{OH})_{6}\right]$ $\mathrm{OH},\left[\mathrm{Cu}_{2} \mathrm{Al}(\mathrm{OH})_{6}\right] \mathrm{OH},\left[\mathrm{Zn}_{2} \mathrm{Cr}(\mathrm{OH})_{6} 6\right] \mathrm{OH},\left[\mathrm{LiAl}_{2}(\mathrm{OH})_{6}\right] \mathrm{OH}$ et al. The main problem of the method of precipitation was formation of fine-disperse amorphous sediment of hydroxides, it making very difficult to filter it and flush it to remove alien ions. Increase of crystallinity was obtained by holding the sediment in mother waters at the temperature range 50-250 ${ }^{\circ} \mathrm{C}$. In this case the sediment appeared to be more acceptable for work, but filtration took too much time. To speed up the process the mother waters were cooled, precipitated and then the sediment was separated by decanting. Then a new portion of flushing water was added, the solution was mixed again and settled. Unfortunately, it is not possible to reach a complete removal of alien cations, that is why these operations were alternated with filtration of the solution in vacuum. The process was repeated until the absence of qualitative reaction for cations in the flushing liquid. After recovery, basic double hydroxides were washed in $\mathrm{KOH}$ solution for deactivation of acid centres and transition of sorbents into basic state.

\subsection{The methods of determination of ammonia content}

The essence of the method is in determining of volatile ammonia by a direct titration with sulphur acid along the reaction. The way of determination: an aliquot part of ammonia water $-10 \mathrm{ml}$ is introduced into a conic bulb, then some distilled water is added, so that the sample's volume should be $100 \mathrm{ml}$ and volatile ammonia is titrated by a solution of sulphur acid until orange methyl indicator acquires pink colour. Afterwards we add 5-7 drops of phenolphthalein indicator into this neutralized solution and $5 \mathrm{ml}$ of $40 \%$ solution of formaldehyde (formalin has to be preliminarily neutralized by $\mathrm{NaOH}$ solution in presence of phenolphthalein until appearance of pinkish colouring). In 2-3 minutes recovered acid is titrated by $\mathrm{NaOH}$ solution until appearance of pinkish coloring [11].

The error of the analysis with acid titrating, i.e. the difference between the evaluations should not exceed $0.02 \mathrm{~g} / \mathrm{l}$.

\subsection{Kinetic investigations}

A sample of excessive water, containing ammonia in different compounds, $200 \mathrm{ml}$ in quantity was loaded into a conic bulb, equipped with a contact thermometer and a reverse cooler, sorbents of various compositions were added and the mixture was mixed on a magnet mixer for a specified time span at certain temperature. Samples for analysis were taken at fixed intervals.

\section{Results and discussion}

The obtained sorbents were investigated for presence of basic sites of different strength (Table 3).

\begin{tabular}{|c|c|}
\hline$\left[\mathrm{Mg}_{2} \mathrm{Al}(\mathrm{OH})_{6}\right] \mathrm{OH}$ & 12.2 \\
\hline$\left[\mathrm{Zn}_{2} \mathrm{Cr}(\mathrm{OH})_{6} 6\right] \mathrm{OH}$ & 15.0 \\
\hline$\left[\mathrm{Mg}_{2} \mathrm{Al}(\mathrm{OH})_{6}\right] \mathrm{OH}$, calcined at $650{ }^{\circ} \mathrm{C}$ & 18.4 \\
\hline$\left[\mathrm{Zn}{ }_{2} \mathrm{Cr}(\mathrm{OH})_{6} 6\right] \mathrm{OH}$, calcined at $6500^{\circ} \mathrm{C}$ & 45.0 \\
\hline
\end{tabular}

Table 3. The basicity of sorbents

3. táblázat A szorbensek bázikussága

On the basis of the obtained data the values of activity of anionic sorbents were compared to the active sites of different strength. The quantity of added sorbent was $0.5 \mathrm{~mol} / \mathrm{mol}$ from concentration of bound ammonia. The reaction flows very rapidly, that is why the temperature was decreased up to $5^{\circ} \mathrm{C}$ to slow it down.

\section{Conclusions}

1. Removal of bound ammonia from excessive waters of coke oven production is possible with application of synthetic anionic clays of different composition.

2. Sorption capability of synthetic anionic clays is determined by concentration of active sites on their surface, the nature of the sites and their basicity.

3. Synthetic anionic clays, having strong active sites are the most efficient sorbents for precipitating ammonia ions.

\section{References}

[1] Butenko E. - Kapustin A. (2009): Adsorption treatment of contaminated water the modified adsorbents. Ecology and industry. Vol 3, pp. 45-48.

[2] Butenko E. - Kapustin A. (2009): Selective adsorption of anionic compounds of the main minerals of different composition. The modern scientific bulletin. - Belgorod. Vol 27 (53), pp. 105-110.

[3] Lurie Y.Y. - Rybnikova A.I. (1963): Chemical analysis of industrial wastewater

[4] Lazarev N.V. - Levina E.N. (1976): Harmful substances in industry. Handbook for chemists, engineers and doctors. Vol. 1. pp. 12-15.

[5] Butenko E. - Kapustin A. (2011): Pollution of the water basin in the industrial region of Mariupol. Ecology and industry. Vol 3, pp. 33-37.

[6] Zubitsky B.D. - Clerks S.N. - Chimari V.A. - Swede V.S. - Sychev S.S. - Nazarov V.G. - Ekgauz V.I. - Dementieva N.V. (2002): Industrial development of new treatment technology of coke oven gas to the destruction of ammonia. Coke and Chemistry. Vol. 5, pp. 27-31.

[7] Platonov O.I. - Egorov V.N. - Lutokhin N.N. - Melnikov I.I. - Chistyakov N.P. - Egorov M.A. - Krinitsyn E.N. - Shchukin R.I. (2005): Features of industrial technology for the catalytic decomposition of ammonia coke. Coke and Chemistry. Vol. 5, pp. 37-41.

[8] Zaretsky M.I. (2003): Isolation of nitrogenous bases of the fractions of coke production. Coke and Chemistry. Vol. 5, pp. 24 - 27.

[9] Koganovsky A.M. - Klimenko N.A. (1990): Adsorption of organic compounds from water.

[10] Karpin G.M. - Chizhov V.M. - Oskin I.S. (2006): The cost-effectiveness of the sulfuric acid method of cleaning coke oven gas from ammonia. Coke and Chemistry. Vol. 4, pp. 36.

[11] Grekova N.N. - Lebedev O.V. - Kapustin A.E. (1997): Problems indicator titration basic heterogeneous catalysts. Ukrainian Chemical Journal. Vol. 1, pp. 25-27.

\section{Ref.:}

Butenko, Eleonora: Sorption reseaches on the removal of the bond ammonia from the wastewater

Építöanyag - Journal of Silicate Based and Composite Materials,

Vol. 71, No. 3 (2019), 84-86. p.

https://doi.org/10.14382/epitoanyag-jsbcm.2019.15 